\title{
ポリオキシエチレン基を有するアルキルホスホネートの 酸性浴中における鉄に対する防食作用*
}

\author{
松田好晴**, 野村 修***, 田村英雄*** \\ **山口大学工学部, ***大阪大学工学部 \\ Inhibiting Effect of Alkylphosphonates with Polyoxyethylene \\ Groups on Corrosion of Iron in Acidic Solution* \\ Yoshiharu Matsuda,** Osamu Nomura*** and Hideo Tamura*** \\ **Faculty of Engineering, Yamaguchi University \\ ***Faculty of Engineering, Osaka University
}

\begin{abstract}
Inhibiting effects of diethyl phosphite, diethyl $\alpha$-hydroxyethyl phosphonate and diethyl $\alpha^{-}$ polyoxyethylene ethylphosphonates on corrosion of iron were studied in sulphuric and hydrochloric acids. Measurements of hydrogen gas evolution, polarization and capacitive impedance were applied. Among the compounds, diethyl $\alpha$-polyoxyethylene ethylphosphonates were excellent inhibitors. They inhibited the cathodic corrosion reaction in sulphuric acid, and the both anodic and cathodic reactions in hydrochloric acid.
\end{abstract}

\section{1. 緒}

言

従来有機腐食防止剂の腐食浴中の金属上への吸着作用 については, 腐食防止剤の窒素, 酸素, 硫黄原子上の孤 立電子対や二重結合, 三重結合の $\pi$ 電子が関与するこ とが多いといわれている1 15)。またすでと報告 ${ }^{14,15)}$ して いるごとく，ポリオキシェチレン基を含む有機化合物が きわめて有効な腐食防止剂であった。そこで本研究では 〉 $\mathrm{P}=\mathrm{O}$ 結合を含む化合物で, しかもポリオキシェチレ ン基を有するアルキルホスホネートを防食剤としてとり あげその防食特性を調べた。このような化合物は水溶性 の物質で, 防食効果は水素ガス発生量の測定, 分極特 性，ならびにインピーダンス測定を行ならことにより調 ベた。

\section{2. 実 験 方 法}

腐食防止剂として用いたものはジェチルホスファイト $\left[\left(\mathrm{C}_{2} \mathrm{H}_{5} \mathrm{O}\right)_{2} \mathrm{POH}\right]$, ジェチル- $\alpha$ ヒドロキシェチルホスホ ネート

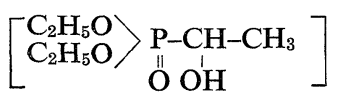

* 電気化学協会第 39 回大会 (昭和 47 年 3 月, 東京) にて発表

** =755 宇部市常磐台 (Tokiwadai，Ube，755, Japan)

*** 干565 吹田市山田上 (Yamadakami, Suita, 565, Japan)
ならびに ジェチルー $\alpha$ ポリオキシェチレンエチルホスホ ネート

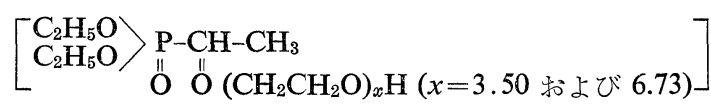

である。後二者は大阪大学工学部阿河研究室において合 成されたものであり，ジェチルー $\alpha$-ヒドロキシェチルホ スホネートはジェチルホスファイトとアルデヒドを塩基 触媒により反応させて合成されたものであり ${ }^{16)}$ ，さらに このものにエチレンオキシドを付加させてポリオキシェ チレン基を導入することによりジェチルー $\alpha$ ーポリオキシ エチレンエチルホスホネートが得られた ${ }^{17) 。}$

これらのらち, ジェチルホスファイトは市販品を精留 $\left(77 \sim 78^{\circ} \mathrm{C} / 20 \mathrm{~mm} \mathrm{Hg}\right)$ してから使用した。 $n_{D^{25}}$ は 1.4060 であった。ジェチルー $\alpha$ ヒドロキシェチルホスホ ネートの場合も, 反応により得られた試料を精留 $\left(71^{\circ} \mathrm{C} /\right.$ $0.05 \mathrm{~mm} \mathrm{Hg}$ ) してから用いた。 $n_{D^{25}}$ は 1.4321 であっ た。な抒，これの生成反応の終点は IR で $2400 \mathrm{~cm}^{-1}$ 付 近の P-H に基づく吸収の消減によって判断し，さらに 試料の構造は IR および NMR で確認されている。

ジェチルー $\alpha$-ポリオキシェチレンエチルホスホネート にエチレンオキシドを無溶媒吹込及法で付加させた が，この場合には一般にほとんど副反応は起こらないと いわれており，ポリオキシェチレン基の生成と末反応物 質の残存量を調べれば，あとはポリオキシェチレン基と しての付加物となったものしかあり学ない。しかし未反 
応のジェチルー $\alpha$ ヒヒドロキシェチルホスホネートは，ほ とんど残っていないことは薄層クロマトグラフィーで確 認されている。生成試料のポリオキシェチレン鎖の長さ は反応前後の重量差より求めた。構造については IR で $2860 \mathrm{~cm}^{-1}$ にェチレン基, $1115 \mathrm{~cm}^{-1}$ にエーテル基によ る吸収が，NMRで $6.4 \tau$ にオキシエチレン基によるシ グナルが認められている。

これらの化合物は室温で水に可溶性であり，1 $\mathrm{N}$ 硫酸 水溶液打よび $1 \mathrm{~N}$ 塩酸水溶液に $10^{-2} \mathrm{~mol} / l$ 以下の任意 の濃度で溶解混合させることができる。したがって本実 験では電解液に分散剂を加えることはしなかった。なお 比較のために一部実験では平均分子量 400 の市販ポリエ チレングリコールを使用した。

鉄試験片としては日新製鋼 K.K. の冷間圧延鋼 (JIS， $\mathrm{SPC}-1$, 厚さ $0.06 \mathrm{~cm}$, 分析值 C 0.08, Mn 0.35, P 0.012, S 0.014, Si 0.01\%) を使用した。分極測定においては試 験片は $1 \mathrm{~cm}$ 幅の矩形状にし, エメリーペーパー\#2000 で研摩した。它の後 $10 \% \mathrm{NaOH}, 10 \% \mathrm{Na}_{2} \mathrm{CO}_{3}$ 混合溶 液中で 10 分間加熱洗浄し水洗後先端 $1 \mathrm{~cm}^{2}$ の又残し他 の部分はダイフロイル \#200で絶縁被覆し, 露出部を 10 $\%$ ヒドラジン水溶液に 10 分間浸漬後十分に水洗して使 用した。水素発生試験に打いては鉄試験片はェメリーペ ーパー\#2000 で研摩後 $1 \mathrm{~cm} \times 1 \mathrm{~cm}$ に切り取り, その 後同様の処理を行なった。容量性インピーダンスの測定 に执いては $2 \mathrm{~mm}$ 幅に切った試験片の先端 $0.04 \mathrm{~cm}^{2}$ を 残し，他部をガラス管中にエポキシ樹脂で封入し，同上 の処理をして用いた。

腐食液には $1 \mathrm{~N}$ 硫酸打よび $1 \mathrm{~N}$ 塩酸を用い，添加す る腐食防止剂の濃度は既報7,81 の有機腐食防止剂につい ての一般的な実験結果と本実験で用いる腐食防止剂の分 子の大きさを考慮して $10^{-4} \mathrm{~mol} / l$ を採用し，試験温度 は $30^{\circ} \mathrm{C}$ とた。

水素発生量から防食率の測定を行ならさいには測定前 に20 分間以上窒素ガスを吹き込んで溶存酸素を除去し た。 $1 \mathrm{~N}$ 硫酸または $1 \mathrm{~N}$ 塩酸 $350 \mathrm{~m} l$ 中に鉄試料片を浸 せきして 30 分ごとに発生する水素ガスを測定し，ガス 発生速度が一定となったのち 6 時間測定した。防食率は 式 (1)から算出した。

$$
\text { 防食率 }=\left[\left(V_{0}-V\right) / V_{0}\right] \times 100(\%)
$$

ここで $V_{0}$ は腐食防止剂を添加しないときの水素発生 量, $V$ は腐食防止剂を入れたさいの水素発生量である。

分極法による腐食の測定装置を Fig. 1 に示す。窒素 ガスの吹き込み口をガラス管で隔離して試験極付近の溶 液の攪汼を防止した。照合電極は硫酸浴の場合には $\mathrm{Hg}$ / $\mathrm{Hg}_{2} \mathrm{SO}_{4} / 1 \mathrm{~N} \mathrm{H}_{2} \mathrm{SO}_{4}$ 極を, 塩酸浴の場合には $\mathrm{Hg} / \mathrm{Hg}_{2} \mathrm{Cl}_{2} /$ $1 \mathrm{~N} \mathrm{HCl}$ 極を使用した。測定前 20 分以上窒素ガスを吹 き込み溶存酸素を除いた。そして測定中も窒素ガスを吹
き込んだ。測定にはポテンシオスタットを用い, 静止電 位よりカソード側に分極させた後，硫酸中で照合電極に 対して $-1.10 \sim-0.80 \mathrm{~V}$, 塩酸中では $-0.70 \sim-0.40 \mathrm{~V}$ の範囲で各測定点ごとに 1 分間分極後の電流值を測定し た。腐食電流は $V-\log i$ 線図に拈いてカソード分極の Tafel 線と腐食電位との交点より求めた8)。これは水溶 液中の鉄上の腐食に拈いて，アノード分極曲線はカソー ド分極曲線にくらべて再現性が悪く，Tafel 線も直線が 得られないことが多いことによるものである。

Fig. 2 にリサージュ図形よりの容量性インピーダンス の測定装置を示す。これは試験片の電位を電池で変化さ

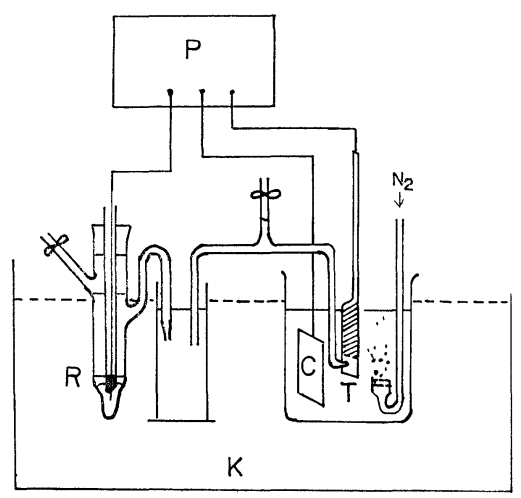

Fig. 1. The arrangement of apparatus for evaluation of corrosion inhibition by poralization measurement. P: potentiostat, $\mathrm{T}$ : test electrode, $\mathrm{R}$ : reference electrode, $\mathrm{C}$ : counter electrode, $\mathrm{K}$ : thermostat.

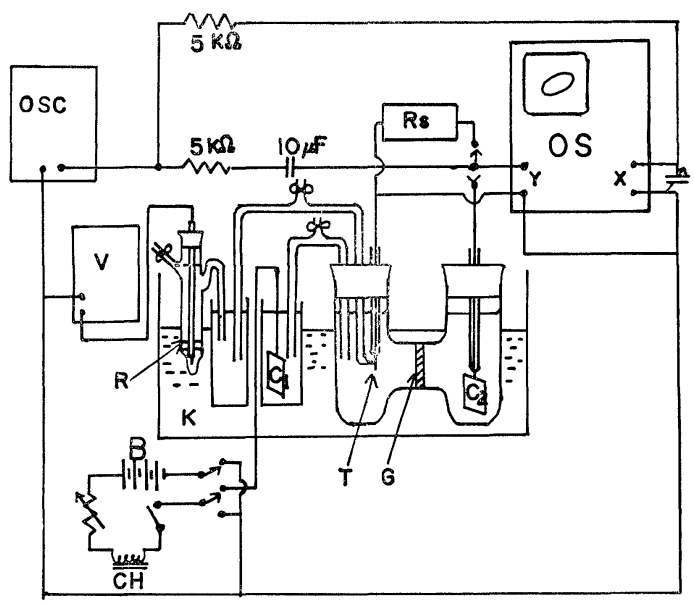

Fig. 2. The arrangement for measurement of impedance. OSC: oscillator, OS: $\mathrm{X}-\mathrm{Y}$ oscilloscope, $\mathrm{T}$ : test electrode, $\mathrm{R}$ : reference electrode, $\mathrm{C}_{1}: \mathrm{C}_{2}$ : counter electrodes, Rs: resistor, V: electrometer, $\mathrm{B}$ : batteries, $\mathrm{CH}$ : choke coil, G: sintered glass diaphragm, $\mathrm{K}$ : thermostats. 


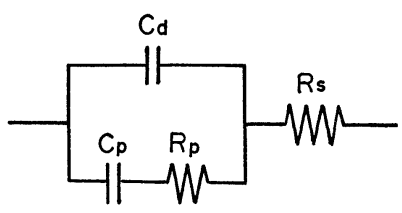

(1)

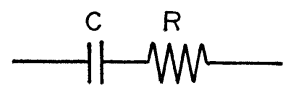

Fig. 3. Equivalent circuits of an electrode system. $\mathrm{C}$ : capacitance, $\mathrm{R}$ : resistance, $\mathrm{Cd}$ : double layer capacitance, $\mathrm{Cp}$ : faradic capacitance of interface, $\mathrm{Rp}$ : faradic resistance of interface, Rs: resistance in electrolytic solution.

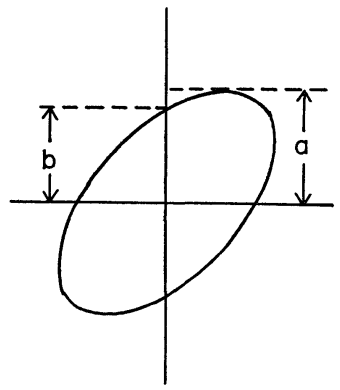

Fig. 4. Lissajous pattern on a X-Y oscillogram.

せて容量性インピーダンスの変化を $X-Y$ オシロスコー プの上に現われるリサージュ困形を観察することによっ て行った ${ }^{18)}$ 。対極には $4 \mathrm{~cm} \times 2 \mathrm{~cm}$ の表面積をもつ白金 板を用い，試験極 $\left(0.04 \mathrm{~cm}^{2}\right)$ に対して電極面積を大き くして対極のインピーダンス変化を無視できるようにし た。溶液に浸された電極表面でのインピーダンスは Fig. 3 の (i) のごとさ等価回路で表わされる。この回路 を(ii) のような簡単な回路におきかえて解析を行なら。 電極に交流電生をかける $X-Y$ オシロスコープ上に Fig. 4 のごとさリサージュ図形が得られる。この図形上 の $\mathrm{a}, \mathrm{b}$ の值より抵抗 $R$ と容量性インピーダンス $1 / \omega C$ を下記の式より計算する。な拉式中の $\varphi$ は位相角, $k$ は 比例定数である。

$$
\varphi=\sin ^{-1}(b / a)
$$

$$
\begin{aligned}
& R=2 a k \cos \varphi \\
& 1 / \omega C=2 a k \sin \varphi
\end{aligned}
$$

\section{3. 結果と考察}

まずジェチルホスファイト， ジェチルー $\alpha$ ーヒドロキシ エチルホスホネートならびに ジェチルー $\alpha$ ーポリオキシェ チレンエチルホスホネート

$$
\left[\begin{array}{c}
\left(\mathrm{C}_{2} \mathrm{H}_{5} \mathrm{O}\right)_{2} \cdot \mathrm{PO} \cdot \mathrm{CH} \cdot \mathrm{CH}_{3} \\
\mathrm{O}\left(\mathrm{C}_{2} \mathrm{H}_{4} \mathrm{O}\right)_{6.73}
\end{array}\right]
$$

を $1 \mathrm{~N}$ 硫酸中で各種濃度で添加した場合の水素発生量よ り求めた防食効果を Table 1 に示す。これらの場合, い ずれの場合にも上記化合物は完全に溶解した。しかしこ の表の 結果によるとジェチルー $\alpha$-ポリオキシェチレンェ チルホスホネートの場合には有効な防食作用が認められ たが前二者については強い防食作用は認められなかっ た。

なおこの表中，ジェチルホスファイトは $10^{-4} \mathrm{~mol} / \mathrm{l}$ に，ジェチルー $\alpha$-ヒドロキシェチルホスホネートは 10-3 $\mathrm{mol} / l$ に防食効果のピークがみられ，いずれも高濃度で 防食効果が低下している。一般には高濃度で一定となる ベきであろらがリン酸エステル類の鉄電極上での挙動は 複雑であり，単なる吸着以外の現象も加わりこのよらな 結果になったと考えられるがその詳細な機構については 不明である。

つぎに上記の結果と従来の研究結果7)よりみて防食率 の差異が明確に現われると考えられる $10^{-4} \mathrm{~mol} / l$ の濃度 に拈ける水素発生量より求めた $1 \mathrm{~N}$ 硫酸扣よび塩酸中に 护ける防食率を Table 2 に示す。この結果からも Table 1 の場合と同様に実験で用いた 2 種のジェチルー $\alpha$-ポリ オキシェチレソエチルホスホネートは硫酸および塩酸浴 中で有効な防食効果を示しているが，エチルホスファイ トとジェチルー $\alpha$ ヒドロキシェチルホスホネートではほ とんど防食効果は認められなかった。な和平均分子量 400 のポリエチレングリコールでもかなりの防食効果が あることから，酸素原子を含み末端に水酸基をもったポ

\begin{tabular}{|c|c|c|c|c|}
\hline \multirow{2}{*}{ Inhibitor } & \multicolumn{4}{|c|}{ Concentration of inhibitor in $1 \mathrm{~N} \mathrm{H}_{2} \mathrm{SO}_{4}$} \\
\hline & $10^{-2} \mathrm{~mol} / l$ & $10^{-3} \mathrm{~mol} / \mathrm{l}$ & $10^{-4} \mathrm{~mol} / \mathrm{l}$ & $10^{-5} \mathrm{~mol} / l$ \\
\hline $\begin{array}{l}\mathrm{C}_{2} \mathrm{H}_{5} \mathrm{O} \\
\mathrm{C}_{2} \mathrm{H}_{5} \mathrm{O}\end{array}>\mathrm{P}-\mathrm{OH}$ & $1.4 \%$ & $6.8 \%$ & $11.4 \%$ & $-3.2 \%$ \\
\hline $\begin{array}{c}\mathrm{C}_{2} \mathrm{H}_{5} \mathrm{O} \\
\mathrm{C}_{2} \mathrm{H}_{5} \mathrm{O}\end{array}>\underset{\mathrm{O}}{\mathrm{P}-\mathrm{OH}}$ & 27.0 & 34.2 & 11.1 & 9.0 \\
\hline 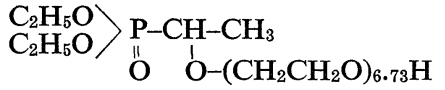 & 87.5 & 82.0 & 75.1 & 58.6 \\
\hline
\end{tabular}
リオキシェチレン基も防食作用に直接関与していると考 えられる。

Table 1. Inhibiting effects as determined by hydrogen evolution (1). 
Table 2. Inhibiting effect as determined by hydrogen evolution (2).

\begin{tabular}{|c|c|c|}
\hline Inhibitor & $\begin{array}{l}1 \mathrm{~N} \\
\mathrm{H}_{2} \mathrm{SO}_{4}\end{array}$ & $\begin{array}{l}1 \mathrm{~N} \\
\mathrm{HCl}\end{array}$ \\
\hline $\begin{array}{l}\mathrm{C}_{2} \mathrm{H}_{5} \mathrm{O} \\
\mathrm{C}_{2} \mathrm{H}_{5} \mathrm{O}\end{array}>\mathrm{P}-\mathrm{OH}$ & $11.4 \%$ & $3.8 \%$ \\
\hline $\begin{array}{l}\mathrm{C}_{2} \mathrm{H}_{5} \mathrm{O} \\
\mathrm{C}_{2} \mathrm{H}_{5} \mathrm{O}\end{array}>\begin{array}{l}\mathrm{P}-\mathrm{CH}-\mathrm{CH}_{3} \\
\stackrel{\mathrm{O}}{\mathrm{OH}}\end{array}$ & 11.1 & -5.0 \\
\hline 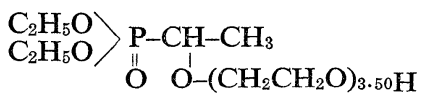 & 64.3 & 55.7 \\
\hline 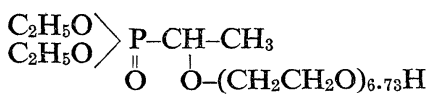 & 75.1 & 63.3 \\
\hline $\begin{array}{l}\mathrm{CH}_{2} \mathrm{OHCH}_{2}\left(\mathrm{OCH}_{2} \mathrm{CH}_{2}\right)_{n} \mathrm{OH} \\
\text { (mean M. W.: 400) }\end{array}$ & 26.5 & 27.6 \\
\hline
\end{tabular}

Concentration of inhitor: $10^{-4} \mathrm{~mol} / l$.

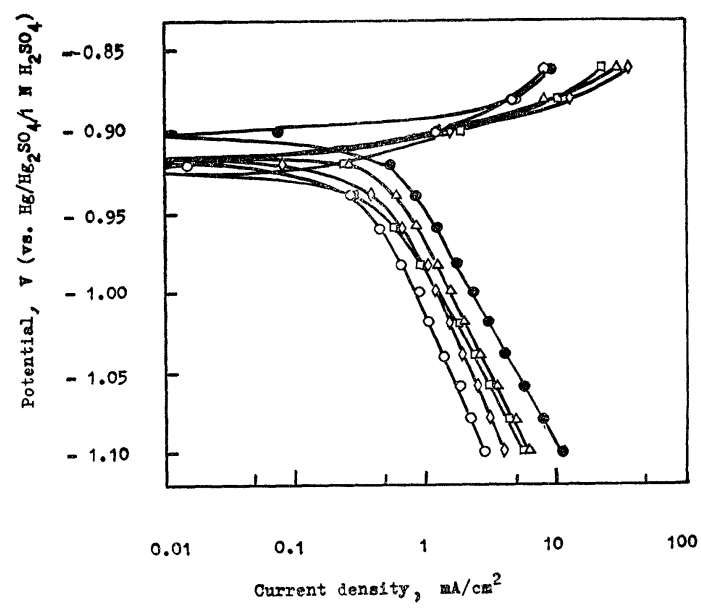

Fig. 5. Polarization curves on iron in sulphuric acid with and without inhibitors.

- - $1 \mathrm{~N} \mathrm{H}_{2} \mathrm{SO}_{4}$,

- $\square$ - $1 \mathrm{~N} \mathrm{H}_{2} \mathrm{SO}_{3}+10^{-4} \mathrm{~mol} / 1$ iter $\left(\mathrm{C}_{2} \mathrm{H}_{5} \mathrm{O}\right)_{2} \mathrm{POH}$,

$-\triangle-: 1 \mathrm{~N} \mathrm{H}_{2} \mathrm{SO}_{4}$

$+10^{-4} \mathrm{~mol} /$ liter $\left(\mathrm{C}_{2} \mathrm{H}_{5} \mathrm{O}\right)_{2} \mathrm{POCHOHCH}_{3}$,

$-\diamond-: 1 \mathrm{~N} \mathrm{H}_{2} \mathrm{SO}_{4}$

$+10^{-4} \mathrm{~mol} /$ liter $\left(\mathrm{C}_{2} \mathrm{H}_{5} \mathrm{O}\right)_{2} \mathrm{POCHCH}_{3}$

Ó $\left(\mathrm{CH}_{2} \mathrm{CH}_{2} \mathrm{O}\right)_{3.50} \mathrm{H}$,

-O-: $1 \mathrm{~N} \mathrm{H}_{2} \mathrm{SO}_{4}$

$+10^{-4} \mathrm{~mol} / \mathrm{liter}\left(\mathrm{C}_{2} \mathrm{H}_{5} \mathrm{O}\right)_{2} \mathrm{POCHCH}_{3}$

$\mathrm{O}\left(\mathrm{CH}_{2} \mathrm{CH}_{2} \mathrm{O}\right)_{6.73} \mathrm{H}$.

つぎに腐食防止剤を含む $1 \mathrm{~N}$ 硫酸水溶液中に浸漬され た鋼板についての分極測定の結果を Fig. 5 に示す。こ の結果をみると試験した 4 種の腐食防止剤はすべて腐食 電流を減少させていた。またこの図をみると，これら腐 食防止剤の添加によりカソード分極が大きくなること と, 腐食電位が卑側に移行することが認められることか ら，これら腐食防止剤では主として硫酸浴中ではカソー ド反応を拈さえることが明らかとなった。

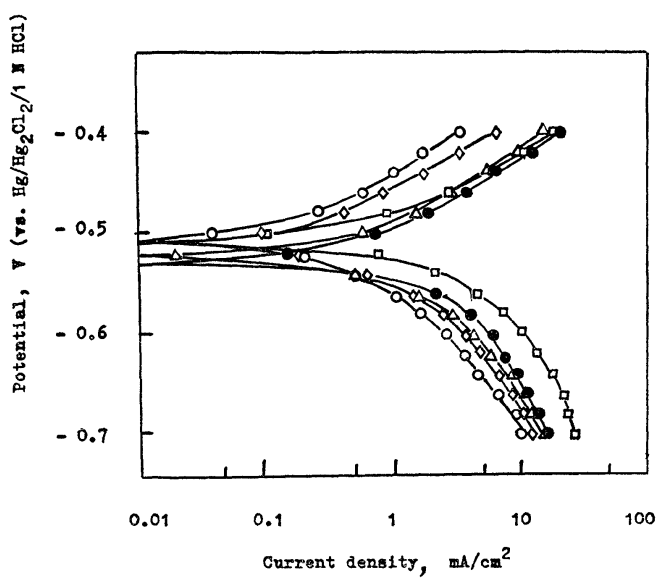

Fig. 6. Polarization curves on iron in hydrochloric acid with and without inhibitors.

- - $1 \mathrm{~N} \mathrm{HCl}$,

- $-: 1 \mathrm{~N} \mathrm{HCl}+10^{-4} \mathrm{~mol} /$ liter $\left(\mathrm{C}_{2} \mathrm{H}_{5} \mathrm{O}\right)_{2} \mathrm{POH}$,

$-\triangle$-: $1 \mathrm{~N} \mathrm{HCl}$

$+10^{-4} \mathrm{~mol} /$ liter $\left(\mathrm{C}_{2} \mathrm{H}_{5} \mathrm{O}\right)_{2} \mathrm{POCHOHCH}_{3}$, $\longrightarrow-: 1 \mathrm{~N} \mathrm{HCl}$

$+10^{-4} \mathrm{~mol} / \mathrm{liter}\left(\mathrm{C}_{2} \mathrm{H}_{5} \mathrm{O}\right)_{2} \mathrm{POCHCH}_{3}$

$-\mathrm{O}-\mathrm{:}: 1 \mathrm{~N} \mathrm{HCl}$
$+10^{-4} \mathrm{~mol} /$ liter $\left(\mathrm{C}_{2} \mathrm{H}_{5} \mathrm{O}\right)_{2} \mathrm{POCHCH}_{3}$ $\mathrm{O}\left(\mathrm{CH}_{2} \mathrm{CH}_{2} \mathrm{O}\right)_{3 \cdot 50} \mathrm{H}$, $\mathrm{O}\left(\mathrm{CH}_{2} \mathrm{CH}_{2} \mathrm{O}\right)_{6.73} \mathrm{H}$.

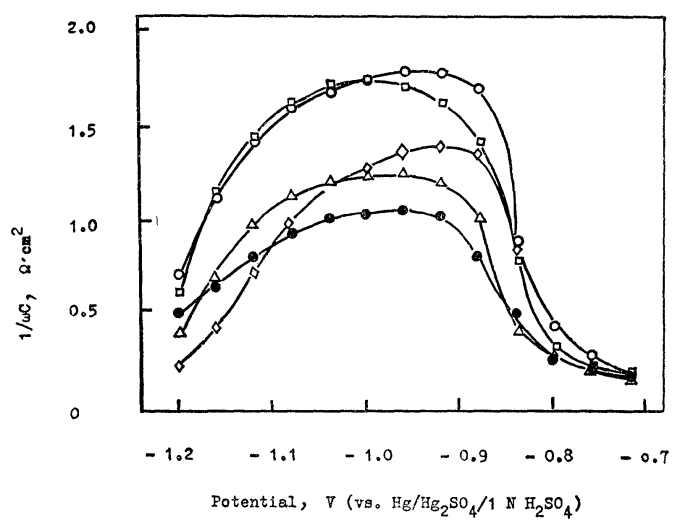

Fig. 7. Relations between capacitive impedance and potential on iron in sulphuric acid with and without inhibitors.

-—: $1 \mathrm{~N} \mathrm{H}_{2} \mathrm{SO}_{4}$,

- $\square$ - $1 \mathrm{~N} \mathrm{H}_{2} \mathrm{SO}_{4}+10^{-4} \mathrm{~mol} /$ liter $\left(\mathrm{C}_{2} \mathrm{H}_{5} \mathrm{O}\right)_{2} \mathrm{POH}$,

$-\triangle-: 1 \mathrm{~N} \mathrm{H}_{2} \mathrm{SO}_{4}$

$+10^{-4} \mathrm{~mol} / \mathrm{liter}\left(\mathrm{C}_{2} \mathrm{H}_{5} \mathrm{O}\right)_{2} \mathrm{POCHOHCH}_{3}$,

$-\diamond-: 1 \mathrm{~N} \mathrm{H}_{2} \mathrm{SO}_{4}$

$+10^{-4} \mathrm{~mol} /$ liter $\left(\mathrm{C}_{2} \mathrm{H}_{5} \mathrm{O}\right)_{2} \mathrm{POCHCH}_{3}$

$\mathrm{O}\left(\mathrm{CH}_{2} \mathrm{CH}_{2} \mathrm{O}\right)_{3.50} \mathrm{H}$,

-O-: $1 \mathrm{~N} \mathrm{H}_{2} \mathrm{SO}_{4}$

$+10^{-4} \mathrm{~mol} / \mathrm{liter}\left(\mathrm{C}_{2} \mathrm{H}_{5} \mathrm{O}\right)_{2} \mathrm{POCHCH}_{3}$

$\mathrm{O}\left(\mathrm{CH}_{2} \mathrm{CH}_{2} \mathrm{O}\right)_{6.73} \mathrm{H}$. 
塩酸浴中に和けるこれら腐食防止剤を添加した場合の 分極曲線を Fig. 6 飞示す。ジェチルホスファイトは防 食効果がなく，またジェチルー $\alpha$ ヒドロキシェチルホス ホネートも防食効果が医とんぞ認められなかった。しか しジェチルーaーポリオキシエチレンエチルホスホネート ではカソード分極もアノード分極も増大し, 明確な防食 効果が認められた。なおこの図中, 腐食防止剂の添加汇 よりカソード側の Tafel 線の傾きが変化しているのは腐 食防止剂の吸着による電極/電解液界面での電気二重層 の変化にともなう Tafel 式の $b$ 保数の変化に上るものと 考觉られる。

腐食防止剤を含む硫酸浴中に浸漬された鋼板について の容量性インピーダンス測定結果を Fig. 7 亿示す。水 素発生の測定抢よび分極測定からみた防食効果が優れて いたジェチルー $\alpha$ ポリオキシェチレンエチルホスホネー トを含めてこれらリン化合物を浴に添加すると容量性イ ンピーダンス值が増大し，これはこれら化合物の防食効 果と対応していることがわかる。この場合, 腐食電位 $\left(-0.91 \mathrm{~V}\right.$ vs. $\left.\mathrm{Hg} / \mathrm{Hg}_{2} \mathrm{SO}_{4} / 1 \mathrm{~N} \mathrm{H}_{2} \mathrm{SO}_{4}\right)$ より卑な電位側で 容量性インピーダンス值が大きくなって路り，これら化 合物の防食効果はカソード反応を抑制することにより生 じていることが明らかである。

さらに塩酸浴中に浸せきした鋼板について同様の測定 をした結果を Fig. 8 亿示す。この場合も水素発生およ

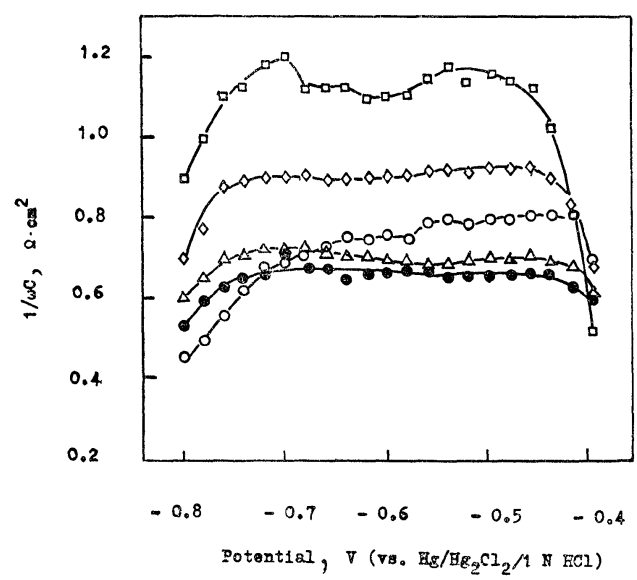

Fig. 8. Relations between capacitive impedance and potential on iron in hydrochloric acid with and without inhibitors.

-1 $1 \mathrm{~N} \mathrm{HCl}$,

——-: $1 \mathrm{~N} \mathrm{HCl}+10^{-4} \mathrm{~mol} / \mathrm{liter}\left(\mathrm{C}_{2} \mathrm{H}_{5} \mathrm{O}\right)_{2} \mathrm{POH}$,

$-\triangle-: 1 \mathrm{~N} \mathrm{HCl}$

$+10^{-4} \mathrm{~mol} /$ liter $\left(\mathrm{C}_{2} \mathrm{H}_{5} \mathrm{O}\right)_{2} \mathrm{POCHOHCH}_{3}$,

$-\diamond-: 1 \mathrm{~N} \mathrm{HCl}$

$+10^{-4} \mathrm{~mol} /$ liter $\left(\mathrm{C}_{2} \mathrm{H}_{5} \mathrm{O}\right)_{2} \mathrm{POCHCH}_{3}$

- $-: 1 \mathrm{~N} \mathrm{HCl}$

$\stackrel{\mathrm{O}}{\mathrm{O}}\left(\mathrm{CH}_{2} \mathrm{CH}_{2} \mathrm{O}\right)_{3.50} \mathrm{H}$,

$+10^{-4} \mathrm{~mol} /$ liter $\left(\mathrm{C}_{2} \mathrm{H}_{5} \mathrm{O}\right)_{2} \mathrm{POCHCH}_{3}$

$\stackrel{\mathrm{O}}{ }\left(\mathrm{CH}_{2} \mathrm{CH}_{2} \mathrm{O}\right)_{6.73} \mathrm{H}$.

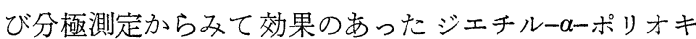
シェチレンエチルホスホネートを浴に添加することによ り容量性インピーダンスが增加して执り，乙かもその傾 向が腐食電位 $\left(-0.53 \mathrm{~V}\right.$ vs. $\left.\mathrm{Hg} / \mathrm{Hg}_{2} \mathrm{Cl}_{2} / 1 \mathrm{~N} \mathrm{HCl}\right)$ から貴 の電位に㨟いても，卑の電位に扟いても認められる。乙 たがって，この化合物は腐食のアノード反応もカソード 反応も抑制することが明らかである。この原因としては 硫酸イオンより特異吸着性のつよい塩素イオンが共存す るとこの化合物の共吸着効果が大きいためではないかと 推定される。

以上とりあげた有機りン化合物の中では分子中にポリ

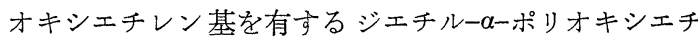
レンエチルホスホネートに高い防食効果があることが明 らかになった。このことはすでに報告した ${ }^{14,15)}$ 硫黄を含 む有機化合物であるアルキルサルファイドにポリオキシ エチレン基を導入することにより優れた腐食防止剂が得 られたことに対応している。本研究ではジェチルホスフ アイトとジェチルー $\alpha$ ヒドロキシェチルホスホネートで は防食効果は極めて低いか, 全く認められなかったが, ポ リオキシェチレン基を導入すると高い防食効果が認めら れた。このようにアルキルホスホネート類に親水性のポ リオキシェチレン基が導入されると腐食防止剂の水との 反発力が 小となりジェチルホスファイトやジェチルー ヒドロキシェチルホスネートに打訬るよりる親水性がま 乙, さらに $>\mathrm{P}=\mathrm{O}$ 基による金属表面との結合を助ける 淰か，Table 2 中でポリエチレングリコールでみられた ようなポリオキシェチレン基中の酸素原子による吸着作 用も加わり，安定な吸着膜が鉄表面に形成され，防食効 果が生じるものと考学られる。この $>\mathrm{P}=\mathrm{O}$ 基の吸着へ の寄与はこの基の $\pi$ 電子によるか, 酸素原子上の孤立電 子対に上るものか明らかでない。しかしこの基の吸着へ の寄与があることは Table 2 でこの化合物の防食率がポ リエチレングリコールの防食率より高いことからも十分 推定されるところである。

な和ジェチルホスファイトにおいては水素発生量から みた防食率が低く，また Fig. 6 の分極特性の測定では ブランク液中よりもこの化合物を添加した浴中における ほうが分極が少なかった。しかしそれにもかかわらず Fig. 8 でこの化合物を浴に添加するとインピーダンス值 が大きくなることからみて，この化合物は電極表面上で 防食作用に寄与しないなんらかの錯形成反応が行なわれ ているのではないかと推定される。

\section{4. 結論}

ジェチルホスファイト，ジェチルー $\alpha$ ヒドロキシェチ ルホスホネートおよび 2 種のジエチルー $\alpha$ ホポリオキシェ チレンエチルホスホネートの $1 \mathrm{~N}$ 硫酸および $1 \mathrm{~N}$ 塩酸浴 
中に括汀る鉄腐食に対する防食効果を水素発生量, 分極 測定, おょび容量性インピーダンス測定より調ベ，以下 の結論を得た。

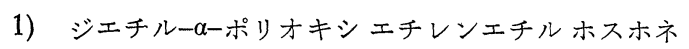
一トでは高い防食効果が認められたが，これはポリオキ シェチレン基が導入されることにより腐食防止剤の水と の反発が小となり安定な吸着膜が鉄表面に形成されるか らであると推定された。

2) ジェチルー $\alpha$-ポリオキシェチレンェチルホスホネ 一トは硫酸浴中では鉄腐食のカソード反応を抑制し, 塩 酸浴中ではカソード反応とアノード反応の再反応を抑制 する。

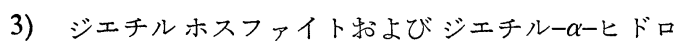
キシエチルホスホネートでは防食作用が弱いか, まった く認められなかった。

本研究を行ならにあたり, 腐食防止剤試料をご提供, また有益なご助言をいただきました大阪大学助教授大城 芳樹氏，ならびに鉄試料をいただきました日新製鋼K.K. 高津正祐氏に謝意を表します。

(Received March 25, 1974)

文献

1) N. Hackerman: Corrosion, 18,332 t (1962).

2）藤井晴一, 荒牧国次: 防蝕技術, 11, 2 (1962).

3) P. E. Cox, R. E. Every \& O. L. Riggs: Corrosion, 20, $229 \mathrm{t}$ (1964).
4) F. M. Donahue \& K. Nobe: J. Electrochem. Soc., 112, 886 (1965).

5) S. Fujii \& G. Aramaki: 3 rd Internatoinal Congress on Metallic Corrosion extended abstracts, Moscow (1966), p. 125.

6) G. W. Poling: J. Electrochem. Soc., 114,1209 (1967).

7) T. Murakawa, T. Kato, S. Nagaura \& N. Hackerman: Corrosion Sci., 8, 341, 483 (1968).

8) 田村英雄, 松田好晴, 飯島 昌：工化, 72, 1077 (1969).

9) Y. Matsuda, Y. Kinuhata, M. Okahara, S. Komori \& H. Tamura: Corrosion Sci., 10, 179 (1970).

10) 中川 哲, 橋詰源蔵：電気化学, 38, 831 (1970).

11）田村英雄, 松田好晴, 衣烟良則, 岡原光男, 小 森三郎：工化, 73, 438 (1970).

12) H. Brandt, M. Fischer \& K. Schwabe: Corrosion Sci., 10, 631 (1970).

13) K. Aramaki: J. Electrochem. Soc., 118, 1553 (1971).

14) Y. Matsuda, K. Kusakabe, H. Yoneyama, I. Ikeda, S. Komori \& H. Tamura: Corrosion Sci., 12, 93 (1972).

15) Y. Matsuda, K. Kusakabe \& H. Tamura: ibid., 13, 587 (1973).

16) F. K. Fields: U.S.P., 2, 579, 810 (1951); H. Zimmer: J. Amer. Chem. Soc., 87, 2777 (1965).

17）大城芳樹, 三木久也, 阿河利男: 油化学, 18, 199 (1969).

18）長浦茂男, 村川享男, 大橋邦夫：電気化学, 30 , 165 (1962). 